\title{
From the Ontology of Social Being to the Law's Ontology
}

\author{
Csaba Varga* \\ Pázmány Péter Catholic University \\ 6 Postal Box, Budapest 8, 1428, Hungary
}

Received 24.08.2015, received in revised form 16.09.2015, accepted 04.10.2015

Social science reconstruction is needed to explain our vital social issues in a theoretical manner. Conceptual differentiations which have laid the foundations of our scientific thought since the era of classical German philosophy (such as phenomenon and essence, or form and content, taken in their duality and/or final synthesis), provide unchangedly the turning points for our methodical thinking and abstract intellectual processing, in variations corresponding to the philosophy and methodology of sciences we cultivate in renewed forms today.

The posthumously published synthesising work of GEORGE LUKÁCS made it clear that all social descriptions have to reckon with socialisation [Sozialisierung/Vergesellschaftlichung] - and with mediation/mediatedness [Vermittlung] within the womb of it - as an unbreakably and irreversibly progressing process, capable of erecting, through their historical accumulations, networks that are complex in themselves. This is the environment that provides the medium within which objectification [Objektivation/Objektivierung] can at all emerge and may turn into an overwhelming power in society, and which can produce, in the course of its self-development, the potential and the social reality of reification [Verdinglichung] that can yet be accepted as functional in social workings, and of alienation [Entfremdung] which is already to be seen as dysfunctional.

It is known from the time of MAINE's inquiry into The Ancient Law one and a half centuries ago at the latest that various kinds of social formalism have already developed since the earliest social formations on, in order to transform human practices and uses more secure and foreseeable, like repetitions within a systemic framework, that is, in order to make them more economical. Social science now designates this trend as conventionalisation, and symbolises and analyses it within the frame and in terms of speech-act theory as its master example. Notwithstanding the fact that LUKÁCS did not enter any such field of research, it is by far not a mere chance that by investigating mediations taking place between the social total complex and its partial complexes, he emphasised language and law as basic agents of mediation, that is, as ones having the sole function to mediate amongst whatever complexes.

Social practices and uses (presupposing co-operation - and thereby also intersubjectivity - by their nature) raise, unavoidably for their theoretical explanation, the question once formulated by classical English philosophising as the dilemma of the separation and/or unity of 'body' and 'soul'. For considering either the formal reconstruction of language (as achieved by SAUSSURE) or the simultaneously differing aspects of law (as revealed by both the clash between KELSEN and EHRLICH in their search for the law's final criterion and POUND's sociologism making the distinction between 'law in books' and 'law in action'), analysis needs the presumption of some construction or constructed structure, on the one hand, albeit it is widely known that actual operation will always break it through, on the other. Otherwise speaking, practical operation is a kind of reconventionalisation which is

(C) Siberian Federal University. All rights reserved

* Corresponding author E-mail address: varga@jak.ppke.hu 
going to be sublated [Aufhebung] at all times. This equals to saying that by incessantly preserving and transcending that which is a given [donné] to it, it will continuously make (in)novations as well according - as adapted - to its own timely needs.

LUKÁCS once draw the conclusion (also by reinterpreting the debate between MARX and LASSALLE on the reception of Roman law) according to which it is the ontological perspective that is primordial vis-à-vis the relevance of any purely epistemological approach. Or, one who acts is driven at any time by his/her specifically individual conditions under the push of his/her recognition of pressing interests. Consequently, just because ideology/ideologisation is part of human societal existence, this is not simply an either true or false form of consciousness but one of the organic and necessary components of the ontology of social existence. To be short: the way we think in is part of what we truly are. Accordingly, so-called juristic world-view [juristische Weltbild], taken as the deontology of the legal profession, is not some accidental and external complementation to law but - be it, characterised as prevailing in ENGELS' time, the case of European continental normativism or the Anglo-Saxon pragmatic casualism or case-law method (not to extend our exemplification to other legal traditions as well) - it is one of the original factors of what can be truly termed as the law's social existence.

Self-realising homogenisations are being built by the partial complexes on the heterogeneity of everyday practice unceasingly. It is the judicial process as particular reality-(re)construction from the analysis of which the author has arrived at the ontologising reformulation of autopoietic theory, originally drafted in Chile in explanation of the biological reproduction of cells. As the author concluded therefrom, that what is alleged as following social patterns is reproduction and production at the same time, an individual combination of preservation and (in)novation up to the point of its being recognised just as exemplary pattern-following by its hic et nunc social environment, and thereby also authenticated as a given instance of the reconventionalisation of the underlying convention. Or, in law, actual decision making can only be modelled by the logic of problem solving, with relatively open chances and within a relatively open referential frame, upon which the logic of justification is only building as added to the former phase to phase posteriorly, as a kind of feedback in test of control; all this running against the usual stand of legal theories which, dreaming about some mechanicity in pattern-following, are only able and willing to report on the implementation of the law's textuality, its sheer realisation in practice. Again, the judicial decision is envisioned as a result concludingly drawn and derived from the letters of the law (in a manner similar to the inner necessity of chemical extraction) - consequently, insofar as the 'right answer' is reached, one without alternatives -, albeit there are no in-built necessities here. LUKACS may have been of the same opinion since he simply designated the settling of the conflict of involved interests through the law's system of fulfilment [Verfüllungssystem] as manipulation.

For comprehension [Verständnis] is again an autopoietical process itself, within the general scheme of any hermeneutic process (unless we think in the possibility of a Robinsonian being, already excluded by LUKACS): it will reach its given form as it will result from the social game (and its just-so-being [Gerade-So-Sein]) occurring in the given auditorium (PERELMAN). In point of principle, everyone may take part in it and everyone may contribute to forming it. The whole process will lead exactly to the result which is still defensible in the given environment as the actual resolution of the conflict of interests involved, just because this is the solution that can yet be successfully conventionalised, that is, recognised and acknowledged in the given medium and in the awareness of the predispositions commonly shared as the individually actualised instance of pattern-following. Accordingly, the personal responsibility of the decision maker (and, in the final analysis, the one of all us) is acutely prevalent in each case here as well. In fact, we are all accountable independently of the fact that, by transferring our responsibility to the quasi-automatic self-operation of our reified structures, we are not used to make it conscious as ascribable to us in person.

This is because homogenisations are never self-propelling: they are nurtured in and by social heterogeneity. Just in the way as professional languages draw inspiration from language uses within the society's general culture and professionals themselves are undivided humans in the fullness of their being, that what is known as the Ausdifferenzierung des Rechts (LUHMANN) can and shall only be realised in practice as reflected through our everyday considerations, that is, in the interest of them, moreover, in order just to implement them to an optimum feasible degree. 
In sum, we are unavoidably responsible for ourselves and for our human destiny, including, of course, the hows and whys, as well as the autonomy, by which we operate our constructs, humanly made for humans' best use.

Keywords: Georg Lukács, socialisation/mediation, objectification/reification/alienation, social formalism, language/law, the law's construction/operation, reconventionalisation as autopoiesis, logic of problem-solving/justification, the law's system of fulfilment and its manipulation, discretion and personal responsibility.

DOI: 10.17516/1997-1370-2015-8-10-2002-2017.

Research area: law.

\section{LUKÁCs and his Ontology of the Social Being}

\section{Categories}

The synthesising work of GEORGE LuKÁCS (1976) made it clear at its time already (Varga 2012a) that social descriptions have to reckon with socialisation [Sozialisierung/ Vergesellschaftlichung] - accompanied by, of course, mediation/mediatedness [Vermittlung] within the womb of it - as an irreversibly and unbreakably progressing process, capable of erecting, through their historical accumulations, networks that are complex in themselves. This is the environment that provides the medium within which objectification [Objektivation/ Objektivierung] can at all emerge and may turn into an overwhelming power in society, and which can produce, in the course of its own selfdevelopment, the potential and the social reality of reification [Verdinglichung] that can yet be accepted as functional in social workings, and of alienation [Entfremdung], which is already to be seen as dysfunctional.

It is known at the latest from the classical time of MAINE's inquiry into The Ancient Law one and a half centuries ago (Maine 1876) that various kinds of social formalism have already developed since the earliest social formations on, in order to transform human practices and uses more secure and foreseeable, like repetitions within a systemic framework, that is, in order to make them more economical in all senses of the word (Lévy-Bruhl 1953). Social science now designates this trend as conventionalisation, and symbolises - when analysing - it within the frame and in terms of speech-act theory as its master example. Notwithstanding the fact that LukÁcs did not enter any such field of research, it is by far not a mere chance that by investigating mediations taking place between the social total complex and its partial complexes, he emphasised language and law as basic agents of mediation (the first for the exclusive chance of social interaction and the second for its frameworking regulation), that is, as ones having the sole function to mediate amongst whatever complexes. This implies the recognition that language and law are not to assert, but to mediate amongst, values and interests which are represented by other complexes in the social total complex. Accordingly, what language and law may still feature up as own values and interests are instrumental at the most - intended either to facilitate mediation or to enhance its cultural level and demanding character (as also asserted by the pope John PaUl II's personal philosophy, Varga 2003).

\section{Legal Relevance}

Social practices and uses raise the question once formulated by classical English philosophising as the dilemma of the separation and/or unity of 'body' and 'soul'.' For considering either the formal reconstruction of language (as achieved by SAUSSURE [1916]) or 
the simultaneously differing aspects of law (as revealed by both the clash between KeLsEN and EHRLICH in their antagonising search for the law's final criterion [Paulson 1992] and Pound's sociologism having once made the distinction between 'law in books' and 'law in action' [Pound 1910]), analysis requires the presumption of some construction of the subject, on the one hand, albeit it is widely known that actual operation will always break it through, on the other (Varga 1973). For motionless, dead language and law, as freely erected imagination, can be the issue of pure abstraction at the most. One, that what is not functioning has no ontological existence either. Conversely expressed, two, that what is functioning as having ontological existence will display some incongruency between ideality and actuality necessarily. That is, practical operation is a kind of reconventionalisation which is going to sublate [aufheben; Aufhebung] its own antecedence(s) at all times.

LuKÁcs once draw the conclusion - also by reinterpreting the debate between MARX and LASSALLE on the nature of the very reception of Roman law (Marx 1861) - according to which it is the ontological perspective that is primordial visà-vis the relevance of any purely epistemological approach. Considering the fact that ideology/ ideologisation is part of human societal existence, ideology/ideologisation is not simply an either true or false form of consciousness but one of the organic and necessary components of the ontology of social existence. To be short: the way we think in is part of what we truly are. Our working consciousness is also co-actor in our actions. Accordingly, so-called juristic worldview [juristische Weltanschaunng/Weltbild], taken as the deontology of the legal profession (Engels \& Kautsky 1887), is not some accidental and external complementation to law but - be it, characterised as prevailing in ENGELS' time, for instance, the case of European continental normativism (of statutory positivism) or the Anglo-Saxon pragmatic casualism (of the caselaw method) (as to their different logics, cf. Varga 2007a) - one of the original factors of the law's social existence. ${ }^{2}$

Self-organising and self-performing homogenisations are being built by the partial complexes upon the heterogeneity of everyday practice unceasingly. It is the judicial process as particular reality-(re)construction from the analysis of which the present author has recently arrived at the ontologising reformulation of autopoietic theory, ${ }^{3}$ originally drafted in Chile in explanation of the biological reproduction of cells and, then, generalised as a methodological tool for macro-sociological theory, too. ${ }^{4}$ As concluded therefrom, that what is alleged to qualify as following social patterns is reproduction and production at the same time, that is, an individual combination of preservation and (in)novation up to the point of all its being recognised just as an exemplary pattern-following by the hic et nunc social environment, and thereby also authenticated as one of the feasible instances of the reconventionalisation of the underlying convention. Or, this is to say that it is "within the canon", which is hardly else than the timely outcome of the self-reconventionalising practice itself (Varga 2014).

There is a particular case of double talk in law, which is necessary if an action pertaining to social heterogeneity is to be performed within, as complying with all the added requirements of, social homogeneity. Accordingly, actual decision making can only be modelled according to the logic of problem solving, with relatively open chances and within a relatively open referential frame, upon which the law's proper logic of justification is only built as added to and projected onto the former, phase to phase and only posteriorly, as a kind of feedback in test of controlling the genuine fulfilment. No need to say that this runs against the 
stand legal theories are used to take, legal theories that, in search for some mechanicity in patternfollowing, are to report on the implementation of the law's textuality, a sheer, direct realisation in (or transposition into) practice (Varga 2011a). Or, the judicial decision is envisioned as a result concludingly derived from the letters of the law (similar to the inner necessity of chemical extraction). LuKÁCs designated the settling of the conflict of involved interests through the law's own system of fulfilment [Verfüllungssystem] as mere manipulation, admitting that ontological description keeps some striking distance from the intimacy and intricacy of any characterisation (or acceptable reconstruction) from within.

\section{Person and Society}

For comprehension [Verständnis] is again an autopoietical process within the general scheme of any hermeneutic process (unless we think in terms of a Robinsonian being, single, and without social memory, as from the beginning excluded by LukÁCs). Comprehension will result from the social game ${ }^{5}$ that just happens to occur in the given audience (Perelman 1997, 36). As to social games of both the heterogeneous and the homogenised fields of action, within which also the simultaneous social interaction of "having a meaning and giving a meaning" (Perelman 1962 ) is to take place, well, in point of principle everyone may take part in them and everyone may contribute to actually shaping them (even if this usually is the prime burden and privilege - and also responsibility - of professionals with specific competences in modern societies). No doubt that, on the final analysis, the whole process will exactly lead to the result which is still defensible in the given environment as the actual resolution of the conflict of interests involved. This is so because this is the solution that can yet be - aware of the predispositions commonly shared - successfully conventionalised, that is, acknowledged in the given medium, as the instance of pattern-following individually actualised hic et nunc. Accordingly, the personal responsibility of the decision maker is acutely prevalent in each case here as well. In fact, we are all accountable - independently of the fact that, by transferring responsibility to the quasi-automatic self-operation of reified structures, we are not used to make it ascribable to anyone in person.

Or, all we act as genuine actors of social games, not simply as imputed puppet entities.

In the ontology of natural and social beings as well, there are no genuine separations, only distinctions or differentiationsmade in, for the sake of, analysis. This is why not even homogenisations are truly self-propelling: they are nurtured in and by social heterogeneity. Just in the way as professional languages draw inspiration from everyday language uses and from the society's general culture (and vice versa, as a traffic in both senses; Varga 2008a), and as professionals themselves always prove to be undivided humans in the fullness (possessing all the facultases) of their personal being (Varga 2006 \& 2010), well, that what is known as the Ausdifferenzierung des Rechts (Luhmann 1981) - standing for the LuKÁcsian legal homogenisation - can only be materialised in practice as reflected through everyday considerations, that is, in the interest of them, moreover, in order just to implement them in practice, to the optimum feasible degree.

Accordingly, in itself reification is hardly more than humanly targeted instrumentalisation, and alienation, just its already pathologised outcome in all-social dimensions, as a kind of degeneration due to lack of purposefully conscious control.

For constraints as purely external powers can only prevail in micro-contextures and at a personal level. Their eventual overdimensioning, exerted either intellectually, morally or otherwise, allows to be exclusively interpreted as their successful 
use in an overweightily ideological form. Or, this is to say that - properly speaking - there are no genuine constraints at a societal level, only states of affairs that may call for reconsideration by opening perspectives to re-assertion or change, up to a socially generalisable cry for reform or revolution, as the case may be.

In sum, we are unavoidably responsible for ourselves and for our human destiny, including the how and why we operate our constructs, humanly made for humans' freely selectible best use.

\section{Outlines of an Ontology of Law}

\section{Foundational Notions}

Reconsidering all the above as reflected on law (Varga 1984), social existence is taken as an irreversible and unbroken process. In this process all that comes about will leave its mark by going to be built as a new component in those conditions under which the mutual effect of the individual complexes and also the self-reproduction of the total complex will take place.

Language and law are complexes destined to nothing but mediation. As such, none of them holds its raison d'être in and by itself. Yet, in order to fulfil their mediatory function, they are expected to develop relative autonomy.

Seen from a historical perspective, the state has ever been taking steps for gradually monopolising law, acquiring an exclusive rule over law. The étatisation of law is completed by such arrangements that separate making the law [Rechtssetzung; création du droit; правотворчество] and administering justice [Rechtsanwendung; application $d u$ droit; правоприменение] ina formalway, bothnotionally and institutionally. In European history, this has been achieved by the development of created, written, and formally enacted norm structures, intended to embody the law exclusively (Varga 2011b). This is the scheme whereby the idea of ius has been reduced to the mere factuality of the lex enacted, i.e., of what has actually been promulgated by the temporary legislator in a procedurally due form. At the same time, however, such a scheme presumes law-making to be lifted almost to limitless all-mightiness, to a freely fillable space of regulatory power. As a consequence, the lex will remain the exclusive genuine actor on a legal field, the sole creator of what can at all be relevant - and in which sense in law. Thereby, law-making is sharply contrasted to law-application, which latter is degraded to a merely executive role. In consequence, justice to be administered will necessarily degenerate into mere formal rule-conformism.

As expressed by Kelsen's Pure Theory of Law - emptying methodically the law's field from anything not distinctively legally posited, for that the genuinely legal determination of the law's construction and operation can be clearly seen - the lawyers' professional approach to the law, alongside with the theoreticians' exclusively conclusive treatment of law, will be exhausted by two principles, pertaining to the law's construction and operation respectively. According to them, validity is a function of the law being properly enacted, and legality is a function of norms and facts in any legal process getting subordinated to, or drawn in conclusion within, a logified normative scheme (Varga 2000 \& 1994).

As to its nature, the norm structure developed by the over-dominant state is a teleological projection which fails to formulate the underlying target that is socially desired to reach (Varga 1971 $\&$ 1981). In order to guarantee unequivocality by excluding mere questionability, it formulates the instrumental behaviour defined by the legislator as the target itself that is to be reached and sanctioned. This is by which the law stipulates the Tatsache - the aggregate of those facts that may constitute a case in law ${ }^{6}$ - so that average social attitudes can be foreplanned and effectively 
reached through prescribing/proscribing (i.e., sanctioning in a positive/negative manner) wellselected instrumental behaviours.

Accordingly, law is expected to fulfil its mediatory function by asserting its own relative autonomy at the same time. That is, it has to realise whatever social targets, transformed into legal ones, through meeting the requirements of its own system of fulfilment. Hence it follows that a definite Janus-facedness, i.e., the practice of double talk, will become a necessary corollary of lawyers' activity. For, what they do is, in fact and according to LukÁcs, firstly, to transfigure real conflicts of interests into conflicts within the law, and then, secondly, to refine even these into apparent or quasi-conflicts, that is, into instances of a genuine application of law - while they seem effectively and exclusively operate with legal enactments according to a linguisticological scheme. Therefore, again, what they do in actual practice is to manipulate the selection of both the "relevant facts" and the "pertinent norms", i.e., their naming accompanied with their interpretation and qualification, so that the judicial decision can eventually imply a responsible social decision under the façade of mere logics. This is to mean that logic is hardly more than a form of expression in this whole operation here, and by far not the ruling medium of reaching the decision that is due.

The same conclusion holds for the why and how of conceptualisations in law as well. For intellectual operations in law are directed to other aims than mere cognition. In the final account, all they are to serve a pragmatic destination, that is, the standardisation of practice: ${ }^{7}$ to classify diverse occurrences, instances and configurations of real life situations by pigeonholing them into a finite number of cases defined by the law. Due to its logically perfect - notional formalism, the qualification according to which a given case is considered to be the case of a construable combination of selected norms has to be achieved completely, up to the formal identification of the former with the latter, and without exception, hesitation, or anything of the ambivalence characteristic of a life lived through, that is, without dialectics - in respect of the legal consequences which are to be meted out in the name and as the provision of the law when the decision will have been eventually made.

The law's self-closure into its own conceptual formalism is crowned by that the self-justification of law - including the manner of how producing and canonising the conditions needed for its valid construction and legally viable operation - will remain an internal question within the sphere of law, made unavailable to any external intervention (Varga 2011c).

\section{Objectification, Reification, Alienation}

Objectification, reification and alienation are heterogeneous categories which by no means overlap, albeit they are historically embedded in the same process: objectification may have a stimulative effect on reification, and reification, on alienation. The reason for all this is rooted in the very nature of social being as an irreversibly progressing process, shaped by all its contributing components, increasingly socialised and mediated themselves. The process is enhanced by the fact that man-made second nature - involving a variety of disanthropomorphising tendencies ${ }^{8}$ in its intellectual processing and ideologisation, too - is increasingly coming to the fore in this process. Law as a construct and law as a practical operation, i.e., the social force of law itself, operated within the framework of its socioprofessional deontology, is just a key instance of it.

Reification is the objectified functioning of the objectifications of social being and/or the reflection of such a functioning as an objectified one. It is to say that reification is the completion 
of objectifications, arranged as items within a self-organising systemic network. Reified functioning and its reified view conform exactly to the demands of formal rationality, which are especially strong and self-serving in public administration and the administration of justice. For there is a socio-political and economic call for constructing and operating some impersonal, quick and safe machinery, suitable to foresee and standardise each and every eventuality. This is why law has come to existence in the social total complex as a specifically heterogeneous partial complex, with strong tendency towards becoming independent, autotelic, and selforganising according to its own laws and rules (Varga 1978). Reified law produces just the ideology that best suits the law's operation according to its own postulates, normative and ideological at the same time. One could also say that the reified operation of reified structures needs and also produces reified consciousness. Well, the juristische Weltanschauung taken as the deontology of the legal profession - perceiving determination by the law in the whole formation and net of relationships in society if legally arranged - can indeed be seen as the adequate reflection of a system turned upside-down. Accordingly, an act of unmasking its sheerly ideological character would both precondition and result in unmasking the law's aspirations to acquire autonomy. ${ }^{9}$

Law as a reified structure never produces the phenomenon of alienation by itself. The total motion of the social total complex is needed for provoking such an effect; and no social arrangement is truly exempt from the chance of its materialisation. It is to be recalled at the same time, however, that explanation needs ontological framework and totality approach within it, as there are no factors in isolation or in neutrality to other factors that could alone produce that effect. For instance, by the law's technicalities, any objectification building into the network of other objectifications will through continuous interaction only reinforce the system of objectifications itself. This is also to say that even tendencies not alienated may tend to create or strengthen alienation (or the subjective impact thereof) in the increasingly differentiated total motion of the social total complex. According to LuKÁCS, "If modes of social conduct, »innocent« in themselves from the point of view of alienation, penetrate everyday life deeply, they will increase the influencing force of modes of conduct which already have a direct effect in this direction; on the other hand, the more their life relations are abstractedly reified and the less they recognise these as concrete and spontaneous processlike relations, the easier people will fall prey to alienation tendencies and the more spontaneously and defencelessly will they be attracted to them [...]. For the more man's everyday life produces alienating forms and life-situations, the easier will the man in the street adjust spiritually and without moral resistance to them as to his »natural surrounding «, and the resistance of average people to really alienating reifications will thereby weaken, although not of necessity in principle." ${ }^{10}$

Modern formal law (Varga 1996) is reified a construct whose operation is reified and reifying at the same time. At the same time, the normativistic deontology of legal practitioners and legal theories are equally founded upon disanthropomorphised schemes, able to exert disanthropomorphising effects themselves. This is why the chance of alienation is at the very root of modern formal law, independently of whether or not there is a political will to transform the law's construction and/or operation into a medium of social alienation.

This is meant by LuKÁCS stating that although alienation is not "a superhistorically general »condition humaine«", however, 
"[i]n a certain sense, one may say that the whole history of mankind is also the history of human alienation ever since a certain degree of the division of labour (most probably since preslavery times)." "11 Moreover, instead of being partial, individual or simply occasional and contingent, "alienation can never be an isolated, self-contained phenomenon, but an element of the economic and social evolution at any time and subjectively that of the ideological reactions to the state, direction of movement, etc. of the society as a whole."12

In sum, alienation - too - has both its origin and its deepening and multiplying effect in the interaction of various social complexes, of a series of objective and subjective factors working in these complexes, in such a way that both the process itself and its outcome can only be explained by the relative positions their components occupy in the social total complex, and never in isolation, never per se. Otherwise speaking, the totality of social being presupposes total interconnections with endless series of allcovering feedback uninterrupted and of relative balance achieved at each time. Accordingly, alienation can only be the outcome produced by some definite total effect.

All in all, objectification, reification and alienation are chances in succession in consideration to which the problem of technics, thematised with dramatic overtone since the late $19^{\text {th }}$ century on, has also to be interpreted. And certainly, not as the embodiment of some fatality but as the potential human self-affirmatory emancipation in mastering the mankind's final destiny, using all means available and feasible without degeneration into states which may tend to become either alienating or alienated.

\section{Conclusion}

All kinds of "artificial human construction"13 are susceptible to grow into an independent power with the tendency of majoring societal life and development in either direction. This is why MARxism (hypothesising a historically formed human nature or Gattungswesen) does not differ basically from the social teaching of the Church in their respective platforms (e.g., Lubac 1950), both drawing a clear dividing line between ultimate values, foundational in and by themselves and therefore to be taken as axioms valid for, e.g., a given culture or historical epoch, on the one hand, and anything else instrumentally developed, whose raison d'être needs particular justification case to case in each occurrence, on the other.

No need to emphasise that alienating tendencies may prevail relating to the noblest catch-words of our civilisational achievements as well. For instance, in Hungary, during the transition from dictatorship to the rule of law a quarter of a century ago, the law's past annihilation and political relativisation was simply replaced by the fetishism of the letter of the law, an outcome channeling the entire transition to a dead end, replacing the de facto past privilege of those ruling politically with a new democratic legitimacy ruling economically now (Varga 1995 \& 2008b). This is to message that even the Rule of Law ideal may corrupt by the simple gesture of a blind or overdimensioned use (Varga 2011d). And the list of examples could be continued for long.

This is one of the reasons why legal philosophy must not be detached from social theorising, arched from anthropology to sociology. This is a cry for unifying our social concerns, in order to harmonise efforts at building kinds of Gesamtplan [total plan], inclusive of all targeted social effects and eventual by-effects as well, and personal responsibility - all through assisted by the principle of subsidiarity with all available local and personal autonomies involved. 
Cf. <http://en.wikipedia.org/wiki/Mind-body_problem $>$ and $<$ http://en.wikipedia.org/wiki/Dualism_(philosophy_of mind)>, as well as <http://www.britannica.com/EBchecked/topic/377923/metaphysics/15815/The-soul-mind-and-body $>$.

2 This is the reason why classical comparative law, conceived of as the mere extension of national legal positivisms themselves, is to be transcended-or, at least, to be complemented to-by the comparative investigation of legal cultures and of the judicial mind (Varga ed. 1992; Varga 2007b).

3 Benseler (1987) in his review article already signalled the tendency of an autopoietic reconstruction in the way Varga (2012a) had in 1985 interpreted the LukÁcsian Ontology, with which the author had in fact got acquainted during his research at the Australian National University Research School of Social Sciences in 1987 (reported in Varga 1991 \& 2012b).

4 Francisco J. Varela \& Humberto R. Maturana in life sciences, resp. Niklas Luhmann \& Gunther Teubner in socio-legal theorising.

5 As developed from the WitTGENSTEINian notion of Sprachspiel. Cf., e.g., <http://en.wikipedia.org/wiki/Language-game>.

6 According to the definition Eisler (1904), „Tatsache (zuerst bei HerDER) ist das, was durch das Denken sicher als Erfahrungsinhalt, als Bestandteil der gesetzlichen Ordnung der Dinge und Ereignisse feststeht. Die »Tatsachen« als solche sind nicht einfach »gegeben«, sondern müssen erst auf Grund der Erfahrung methodisch-denkend gesetzt, konstatiert werden.” As to its context (Gschnitzer 1992), „1. Rechtssätze bestehn aus Tatbestand und Rechtsfolge (Gesetzesbefehl); aus Sein (abstrakter Tatbestand) und Sollen (abstrakte Rechtsfolge). 2. Damit die Rechtsfolge eintritt, muß die konkrete Sachlage, der Sachverhalt (der 'Fall') unter den abstrakten Tatbestand subsumiert werden können, dh. geprüft werden, ob der Sachverhalt die Merkmale des Tatbestandes erfüllt. 3. Eine Tatsache, die allein oder zusammen mit andern eine Rechtswirkung herbeiführt, ist eine juristische Tatsache."

7 The issue of whether or not norm propositions are themselves descriptive statements with truth value suitable to be proven or falsified used to be a test of universality of the LeNINist reflection theory-standing for the epistemologisation of ontology itself-in Central Europe's communist MARxism in the 1950s and 1960s. Any criticism was held to undermine its final truth. For an attempt notwithstanding in 1964, ending in prohibition all through, see Varga 2001.

8 E.g., LuKÁCS tells about "disanthropomorphising thought apparatuses” [,,desanthropomorphisierende Gedankenapparaturen"]-in Georg Lukács Die wichtigsten Problemkomplexe [M/120 Manuskript at Lukács Archives and Library, Hungarian Academy of Sciences, Budapest], p. 922-for which law provides a prime exemplification.

9 LUKÁCS' characterisation of reification being "of purely ideological nature in reality” [,,in Wirklichkeit rein ideologischen Beschaffenheit" in his MS idem., pp. 161-162] is in contrast with his underlying view of its thoroughly ontological [seinhaftige] function and functioning.

10 Idem., p. 298. [„einerseits verstärken vom Standpunkt der Entfremdung an sich »unschuldige« gesellschaftliche Verhaltungsarten, wenn sie tief ins Alltagsleben eindringen, die Durchschlagskraft jener, die bereits direkt in dieser Hinsicht wirken, andererseits werden die Einzelmenschen desto leichter von Entfremdungstendenzen erfaßbar - man könnte sagen: inklinieren desto spontaner und widerstandunfähiger auf diese -, je mehr ihre Lebensbeziehungen abstrahierend verdinglicht und nicht als konkret, spontan prozeßhaft wahrgenommen werden [...]. Denn je mehr das Alltagsleben der Menschen - vorläufig noch im bisher angegebenen Sinn - verdinglichende Lebensformen und Lebenssituationen schafft, desto leichter wird der Mensch des Alltagslebens sich diesen ohne geistig-moralischen Widerstand als »Naturgegebenheiten «, geistig anpassen, und dadurch kann im Durchschnitt - ohne prinzipiell notwendig zu sein - ein abgeschwächter Widerstand gegen echte, entfremdende Verdinglichungen entstehen.’]

1 Lukács Die wichtigsten Problemkomplexe [MS], p. 15 and p. 573. [„eine allgemeine überhistorische »condition humaine «” / „In bestimmtem Sinn könnte man sagen, daß die ganze Menschheitsgeschichte von einer bestimmten Höhe der Arbeitsteilung (wahrscheinlich schon von der der Sklaverei) auch die der menschlichen Entfremdung ist."]

12 Idem., p. 755. [, ,die Entfremdung niemals etwas Isoliertes, Aufsichselbstgestelltes sein kann, sondern objektiv ein Moment der jeweiligen ökonomisch-sozialen Entwicklung, subjektiv ebenfalls ein Moment der ideologischen Reaktionen der Menschen auf Stand, Bewegungsrichtung etc. der Gesamtgesellschaft ist, muß natürlich auch hier festgehalten bleiben.”]

13 Klaus 1958, 72 terms 'künstliche menschliche Konstruktionen' the propositions which, considering their purely praxisbound nature, directly have no cognitive contents and-consequently-cannot be taken as either true or false.

\section{References}

Benseler, F. (1987). [review on Varga 2012 (1985).] Zeitschrift für Rechtssoziologie, 8(2), pp. 302304.

Eisler, R. (1904). Wörterbuch der philosophischen Begriffe. Available at: http://www.textlog. de/5224.html (accessed 10 April 2015).

Engels, Fr. \& Kautsky, K. Jurist-socialism [Juristen-Sozialismus] [1887]. in: Marx, K. \& Engels, Fr. (1962). Werke, vol. 21. Berlin[-East], Dietz Verlag, 1962. pp. 491-509. Available also at: http://www. mlwerke.de/me/me21/me21_491.htm (accessed 10 April 2015).

Gschnitzer, Fr. (1992). Allgemeiner Teil des bürgerlichen Rechts. 2. neuarbeitete Aufl. Wien $\&$ New York, Springer, 1992. Available also at: http://books.google.hu/books?id=d9DTGBjPOwkC $\& p g=P A 447 \& l p g=P A 447 \& d q=\% 22$ juristische + tatsache $\% 22 \&$ source $=$ bl $\&$ ots $=u 1$ AC29212f $\&$ sig $=\mathrm{m}$ 
wqOdNY6PUUiySBtYnWt-OHyOeE\&hl=hu\&ei=B_i4St-IK9WNsAachOG3BQ\&sa=X\&oi=book_r esult $\& \mathrm{ct}=$ result $\&$ resnum $=6 \# \mathrm{v}=$ onepage $\& \mathrm{q}=\% 22 \mathrm{juristische} \% 20$ tatsache $\% 22 \& \mathrm{f}=$ false $($ accessed 10 April 2015).

Klaus, G. (1958). Einführung in die formale Logik. Berlin[-East], VEB Deutscher Verlag der Wissenschaften. xii+391 pp.

Lévy-Bruhl, H. (1953). Réflexions sur le formalisme social. Cahiers internationaux de Sociologie $X V(1)$. pp. 53-63.

Lubac, H. de, SJ. (1950). Le Drame de l'humanisme athée. Paris, Spes. 415 pp.

Luhmann, N. (1981). Ausdifferenzierung des Rechts: Beiträge zur Rechtssoziologie und Rechtstheorie. Frankfurt am Main, Suhrkamp. 456 pp.

Lukács, Gy. (1976). A társadalmi lét ontológiájáról. Vol. I-III. Budapest, Magvető. \{vol. III translated in Russian, Лукач, Д. (1991). К онтологии общественного бытия: Пролегомены / пер. с нем. И. Н. Буровой \& М. А. Журинской, общ. ред. и вступ. ст. И. С. Царский \& М. А. Хевеши. М.: Прогресс. 410 p. Available also at: http://www.civisbook.ru/files/File/Lukach_K\%20ontologii.pdf (accessed 10 April 2015).

Maine, H. J. S. (1876). The Ancient Law: Its Connection with the Early History of Society, and Its Relation to New Ideas. London, John Murray. viii+415 pp.

Marx, K. letter to Lassalle, F. (22 July 1861), in: Marx, K. \& Engels, Fr. (1985). Collected Works. Vol. 41. Moscow, Progress Publishers. p. 316.

Paulson, St. L. (1992). Hans Kelsen und die Rechtssoziologie: Auseinandersetzungen mit Hermann U. Kantorowicz, Eugen Ehrlich und Max Weber. Aalen, Scientia-Verlag.

Perelman, Ch. (1962). Avoir un sens et donner un sens. Logique et Analyse, No. 5. pp. 235-250.

Perelman, Ch. (1997). L'empire rhétorique: Rhétorique et argumentation. Paris, Vrin. 194 pp.

Pound, R. (1910). Law in Books and Law in Action. American Law Review 44(1), pp. 12-26.

Saussure, F. de (1916). Cours de linguistique générale. Lausanne \& Paris, Payot. 336 pp.

Varga, Cs. (1971). The Preamble: A Question of Jurisprudence. Acta Juridica Academiae Scientiarum Hungaricae XII(1-2), pp. 101 - 128. Available also at: http://ssrn.com/abstract=2389608 (accessed 10 April 2015).

Varga, Cs. (1973). Quelques questions méthodologiques de la formation des concepts en sciences juridiques. Archives de Philosophie du Droit, XVIII, pp. 205-241.

Varga, Cs. (1978). La question de la rationalité formelle en droit: Essai d'interprétation de l'Ontologie de l'être social de Lukács. Archives de Philosophie du Droit, 23, pp. 213-236.

Varga, Cs. (1981). Die ministerielle Begründung in rechtsphilosophischer Sicht. Rechtstheorie, 12(1), pp. 95-115.

Varga, Cs. (1984). Towards the Ontological Foundation of Law (Some Theses on the Basis of Lukács' Ontology). In: Curiel B., J. L. (coord.). Filosofía del Derecho y Problemas de Filosofía Social, $X$. México, Universidad Nacional Autónoma de México. pp. 203-216. Available also at: http://biblio. juridicas.unam.mx/libros/3/1051/20.pdf (accessed 10 April 2015).

Varga, Cs. (1991). Judicial Reproduction of the Law in an Autopoietical System? In: Krawietz, W., Martino, A. A. \& Winston, I. I. (hrsg.). Technischer Imperativ und Legitimationskrise des Rechts. Berlin, Duncker \& Humblot. pp. 305-313. 
Varga, Cs. (1994). Kelsen's Theory of Law-application: Evolution, Ambiguities, Open Questions. Acta Juridica Hungarica 36 (1994) 1-2, pp. 3-27 \& < http://papers.ssrn.com/sol3/papers.cfm?abstract_ id $=2389697>$

Varga, Cs. Transition to Rule of Law On the Democratic Transformation in Hungary (Budapest: ELTE “Comparative Legal Cultures" Project 1995) 190 pp. [Philosophiae Iuris] \& <http:// drcsabavarga.wordpress.com/2010/10/24/transition-to-rule-of-law-on-the-democratic-transformationin-hungary-1995/>.

Varga, Cs. 'The Basic Settings of Modern Formal Law' in European Legal Cultures ed. Volkmar Gessner, Armin Hoeland \& Csaba Varga (Aldershot, Brookfield USA, Singapore, Sydney: Dartmouth 1996) xviii +567 pp. [Tempus Textbook Series on European Law and European Legal Cultures 1], introduction to Part II: »The European Legal Mind«, pp. 89 - 103.

Varga, Cs. 'Validity' Acta Juridica Hungarica 41 (2000) 3 - 4, pp. 155 - 166.

Varga, Cs. 'A magatartási szabály és az objektív igazság kérdése' [Rule of behaviour and the question of objective truth, 1964] in his Útkeresés Kísérletek - kéziratban [Searching for a path Unpublished essays] (Budapest: Szent István Társulat 2001) 167 pp. [Jogfilozófiák], pp. 4 - 18 \& <http:// drcsabavarga.wordpress.com/2012/12/26/varga-csaba-utkereses-kiserletek-keziratban-2001/>

Varga, Cs. 'Buts et moyens en droit' in Giovanni Paolo II Le vie della giustizia: Itinerari per il terzo millennio (Omaggio dei giuristi a Sua Santità nel XXV anno di pontificato) a cura di Aldo Loiodice \& Massimo Vari (Roma: Bardi Editore \& Libreria Editrice Vaticana 2003), pp. 71 - 75 \{also <http://www.thomasinternational.org/projects/step/conferences/20050712budapest/varga1. $\mathrm{htm}>$ and 'Constitutions and Constitutionalism in Relation of GOALS-and-MEANS IN Axiology and in Law' in Конституцุия, конституционализм, конституциионализация правовых систем: актуальное соотношение понятий и трендов: сборник статей по материалам Международной научно-практической конференции, посвященной двадцатилетию Конституции Российской Федерации, г. Тверь, 17 - 18 мая 2013 года, ред. В. И. Крусс (Тверь: Тверьскнй государственний университет 2013), pp. $400-407\}$.

Varga, Cs. 'Theory and Practice in Law: On the Magical Role of Legal Technique' Acta Juridica Hungarica 47 (2006) 4, pp. 351 - $372 \&<$ http://www.akademiai.com/content/j4k2u58xk7rj6541/ fulltext.pdf $>$

Varga, Cs. 'Law, Understanding of Law, Application of Law' Acta Juridica Hungarica 51 (2010) 2, 20 - 32 pp. \& <http://www.akademiai.com/content/05w03576k7113704/>

Varga, Cs. 'Differing Mentalities of Civil Law and Common Law? The Issue of Logic in Law' Acta Juridica Hungarica 48 (2007a) 4, pp. 401 - 410 \& <http://www.akademiai.com/content/ b0m8x67227572219/>

Varga, Cs. 'Law and its Doctrinal Study (On Legal Dogmatics)' Acta Juridica Hungarica 49 (2008a) 3, pp. 253 - $274 \&<$ http://www.akademiai.com/content/g352w44h21258427/> \{“Правовая доктрина: Методология и онтология' Право Украинь Юридический журнал [Киев] (2011) 11 12 , pp. $94-103\}$.

Varga, Cs. Transition? To Rule of Law? Constitutionalism and Transitional Justice Challenged in Central \& Eastern Europe (Pomáz: Kráter 2008b) 292 pp. [PoLíSz series 7] \& <http://drcsabavarga. wordpress.com/2010/10/25/varga-transition-to-rule-of-law- - - constitutionalism-and-transitionaljustice-challenged-in-central-and-eastern-europe-2008/> 
Varga, Cs. 'Law, Understanding of Law, Application of Law' Acta Juridica Hungarica 51 (2010) 2, 20 - 32 pp. \& <http://www.akademiai.com/content/05w03576k7113704/>.

Varga, Cs. Theory of the Judicial Process The Establishment of Facts [1992/1995] $2^{\text {nd }}$ \{reprint\} ed. with Postfaces I and II (Budapest: Szent István Társulat 2011a) viii + 308 pp. \& <http:// drcsabavarga.wordpress.com/2012/03/13/varga-theory-of-the-judicial-process-the-establishment-offacts-19952011/>.

Varga, Cs. Codification as a Socio-historical Phenomenon [1979/1991] $2^{\text {nd }}$ \{reprint\} ed. with an Annex \& Postscript (Budapest: Szent István Társulat 2011b) viii + 431 pp. \& <http://drcsabavarga. wordpress.com/2010/10/25/varga-codification-as-a-socio-historical-phenomenon-1991/>.

Varga, Cs. 'Law, Legal Process and the Judicial Mind' Российский юридический журнал [Екатеринбург] 6 (2011c) 4 (No. 79), pp. 5 - 13 \& <http://electronic.ruzh.org/?q=node/260>.

Varga, Cs. 'Верховенство права или дилемма идеала: садоводство против механизации' in Проблемь модернизачии правовой системь современного российского общества Международная научная конференция (г. Красноярск, 30 сентября - 1 октября) ред В. М. Шафаров, I (Красноярск: Центр информации 2011d), pp. 14 - 26 \& < http://aw.sfu-kras.ru/files/ users/problevs_modern_1.pdf>.

Varga, Cs. The Place of Law in Lukács' World Concept [1981/1985] 3 $3^{\text {rd }}$ \{reprint\} ed. with Postface (Budapest: Szent István Társulat 2012a) 218 pp. \& <http:/drcsabavarga.wordpress.com/2012/03/13/ the-place-of-law-in-lukacs-world-concept-19852012/>.

Varga, Cs. The Paradigms of Legal Thinking [1996/1999] enlarged 2 $2^{\text {nd }}$ ed. (Budapest: Szent István Társulat 2012b) 418 pp. [Philosophiae Iuris] \& <http://www.scribd.com/doc/85083788/VARGAParadigmsOfLegalThinking-2012>.

Varga, Cs. Comparative Legal Cultures ed. Csaba Varga (Aldershot, Hong Kong, Singapore, Sydney: Dartmouth \& New York: The New York University Press 1992) xxiv + 614 pp. [The International Library of Essays in Law \& Legal Theory, Legal Cultures 1].

Varga, Cs. 'Comparative Legal Cultures? Renewal by Transforming into a Genuine Discipline' Acta Juridica Hungarica 48 (2007b) 2, pp. 95 - 113 \& < http://www.akademiai.com/content/ gk485p7w8q5652x3/fulltext.pdf>.

Varga, Cs. 'Jog és nyelv? Gondolatok egy alapvetéshez' [Law and language? Contributions of outlining their relationship] Glossa Iuridica I (2014) II, pp. 85 - 100. 


\title{
От онтологии общественного бытия
}

\section{к онтологии права}

\author{
Чаба Варга \\ Католический университет Петера Пазманя \\ Венгрия, 1428, Будапешт 8, Почтовый ящик, 6
}

Реконструкиия социильной науки необходима для теоретического объяснения наших жизненно важных соииальных проблем. Концептуальные дифференциации, которые легли в основу нашей научной мысли начиная с эпохи классической немечкой философии (такие как феномен и его сущность, или форма и содержание, рассматриваемые в их дуализме и/ или заключительном синтезе), неизменно остаются поворотными точками для нашего методического мышления и абстрактной интеллектуальной обработки информации, относящиеся к философии и методологии наук, которыми мы сегодня занимаемся в новом формате.

После посмертного объединенного издания работ Дьёрдя Лукача стало ясно, что все социальные описания должны принимать во внимание сочиализацию [Sozialisierung/ Vergesellschaftlichung] и посредничество [Vermittlung] в их истоках - как неразрывный и безвозвратно прогрессирующий процесс, способный возводить через свои исторические накопления сети, сложные сами по себе. Это окружение, которое создает среду для потенциального возникновения объективации [Objektivation/Objektivierung], которая может превратиться в всепоглощающую силу в обществе, и которое в ходе своего саморазвития создает потенциал и социальную реальность овеществления [Verdinglichung], что может быть принято в качестве эффективного в сочиальных условиях, и отчуждения [Entfremdung], которое уже может рассматриваться как неэффективное.

С момента исследования Генри Мэна в работе ««Древнее право» полтора столетия назад известно, что различные виды сочиального формализма уже развиты начиная с самых ранних общественных формачий для того, чтобы сделать человеческие традиции и их использование более безопасными и предсказуемыми, как повторения в рамках системы, т.е. более экономичными. В сочиологии данная тенденция в настоящее время обозначается как конвенционализация, которую характеризуют и анализируют в рамках теории речевого акта, используя ее в качестве эталона. Несмотря на то что Лукач не затрагивал эти сферы в своих исследованиях, при изучении посредничества между сочиальным общим комплексом и его частичными комплексами он далеко не случайно подчеркнул, что язык и право являются основными субъектами посредничества, т.е. выполняют исключительную функцию посредника между любыми комплексами.

Количество сочиальных традиичй и их применение (по своей природе предполагающее сотрудничество и в этой связи межсубъективность) растет, независимо от их теоретического объяснения: вопрос, сформулированный однажды классической английской философией как дилемма разделения и/или единства «тела» и «души». Для рассмотрения формальной реконструкиии языка (как предложил Соссюр) либо одновременно различных аспектов права (как было выявлено Кельзеном и Эрлихом в результате их спора в поиске окончательного критерия права и представлено в сочиологизме Паунда, различающего «закон в книге» и «закон в действии»), требуется допущение какой-либо конструкиии или сконструированной структуры, с одной стороны, хотя, с другой стороны, широко известно, что фактическое применение всегда будетломатьее. Иначеговоря, практическое применение является своего рода реконвенционализаџией, которая будет упраздняться [Aufhebung] во все времена. Это равнозначно тому, что, постоянно сохраняя и превосходя то, что ему дано [donпе́], применение на практике всегда будет вносить (ин)новации, а также реализовывать своевременную адаптаџию возникающим потребностям. 
Лукач однажды пришел к выводу (также интерпретируя дебаты между Марксом и Лассалем на тему принятия римского права), согласно которому это онтологическая перспектива, которая является первичной по отношению к актуальности любого чисто гносеологического подхода. Или же тот, кто совершает действие, в любое время руководствуется своими собственными индивидуальными условиями под давлением признания своих актуальных интересов. Следовательно, только потому, что идеология/идеологизация является частью существования человека в обществе, это не просто истинная или ложная форма сознания, но и один из органических и необходимых компонентов онтологии общественного бытия. Проще говоря, то, как мы думаем, является отчасти тем, что мы есть на самом деле. Соответственно, так называемое юридическое мировоззрение [Juristische Weltbild], принимаемое в качестве деонтологии юридической профессии, - это не какое-то случайное и внешнее дополнение к закону, но характеризуемьй как преобладаюший во времена Энгельса случай европейского континентального нормативизма или англосаксонского прагматического казуализма, или метод прецедентного права (не будем затрагивать другие примеры правовых традиций) - это один из первичных факторов, который можно по-настоящему назвать социальным существованием закона.

Самореализуемые гомогенизачии бесконечно надстраиваются над неоднородной повседневной практикой в виде частичностей. Это судебный процесс как отдельная реальность-(ре)конструкия, в ходе анализа которого автор пришел к онтологизации переформулировки автопоэтической теории, которая первоначально была разработана в Чили для объяснения биологического воспроизводства клеток. В этой связи автор отмечает, что то, что утверждается как сочиальные структуры, является одновременно как воспроизводством, так и производством, своеобразным сочетанием сохранения и (ин)новачии до того момента, когда они признаются своей сочиальной средой в качестве показательного образиа для подражания и, таким образом, также аутентифииируются как заданные экземпляры реконвенционализации базовых традиций. Или - по закону фактическое принятие решений может быть смоделировано только логикой решения проблемы, с относительно открытыми шансами и в относительно открытой справочной форме, над которой логика обоснования надстраивается только как дополнение к предыдущей фазе для последующего формирования, как своего рода обратная связь. Все это работает против обычных правовых теорий, которые, мечтая хоть о какойто механичности в следовании образцам, могут и готовы сообщать об осуществлении текстуальности права, его чистой реализаиии на практике. Опять же судебное решение определяется исходя из буквы закона (по аналогии с внутренней необходимостьюхимической экстракиии), соответственно, поскольку «правильный ответ» получен, единственный и безальтернативный, никаких встроенных необходимостей здесь нет. Лукач, возможно, был того же мнения, так как он обозначил конфликт вовлеченных интересов при выполнении системы права [Verfüllungssystem] как обычную манипуляцию.

Так как понимание [Verständnis] само по себе является автопоэтическим проиессом, в рамках общей схемы любого герменевтического прочесса (если мы не рассматриваем робинзонское бытие, которое Лукач уже исключил) оно достигнет своей заданной формы в результате соииальной игры (и ее простого существования [Gerade-So-Sein]) в определенной аудитории (Перельман). Так, в частности, каждый может принять участие и каждый может внести свой вклад в его формирование. Весь проиесс приведет именно к тому результату, который до сих пор является оправданным в данной среде как фактическое разрешение конфликта вовлеченных интересов, только потому, что это то решение, которое еще может быть успешно конвенционализировано, т.е. признано и принято в данной среде с пониманием общепризнанных предрасположенностей как индивидуальной формы следования шаблону. Соответственно, личная ответственность за принятие решений (и в конечном счете ответственность каждого из нас) присутствует в каждом случае. На самом деле мы все несем ответственность, независимо от того, что, перекладывая нашу ответственность на квазиавтоматическую самостоятельную работу наших абстрактных структур, мы не 
привыкли к тому, чтобы она была осознанной, в отличие от того, когда она приписывается нам лично.

Это связано с тем, что гомогенизация никогда не будет самодвижущейся: она подпитывается сочиальной неоднородностью. Так же как профессиональные языки черпают вдохновение из использования языка в рамках общей культуры и сами специалисты являются цельными людьми в полноте своего бытия, т.е. то, что известно как разделение прав [Ausdifferenzierung des Rechts] (Луман), может и должно быть реализовано на практике как это отражено в наших повседневных рассуждениях, т.е. в их интересах и -более того - для того чтобы просто реализовать их до оптимальной возможной степени.

В иелом, мы неизбежно несем ответственность за себя и за нашу человеческую судьбу, включая вопросы «как и почему», а также автономию, которую мы даем нашим структурам, сделанным человеком на благо человека.

Ключевые слова: Дьёрдь Лукач, сочиализачия/посредничество, объективация/овеществление/ отчуждение, сочиальныци формализм, язык/закон, построение/функиионирование права, реконвениионализачия как самосотворение, логика решения проблем/обоснование, система реализачии права и управление ей, свобода действий и личная ответственность.

Научная специальность: 12.00.00 - юридические науки. 